\title{
Bronchitis in two integrated steel works III. Respiratory symptoms and ventilatory capacity related to atmospheric pollution
}

\author{
C. R. LOWE, H. CAMPBELL, and T. KHOSLA \\ Department of Social and Occupational Medicine, Welsh National \\ School of Medicine, Cardiff
}

\begin{abstract}
Lowe, C. R., Campbell, H., and Khosla, T. (1970). Brit. J. industr. Med., 27,121-129. Bronchitis in two integrated steel works. III. Respiratory symptoms and ventilatory capacity related to atmospheric pollution. This is the third in a series of papers presenting the results of an epidemiological study of respiratory symptomatology and lung function among men employed in two integrated steel works in South Wales. In this paper measurements of atmospheric pollution are related to respiratory symptoms and ventilatory capacity among 10449 men who spent the greater part of their working hours in one or other of 114 defined working areas.

The problem has been explored in three different ways. In the first, each man was assigned the mean value of sulphur dioxide and respirable dust for the area in which he was working and this was related to his ventilatory capacity $\left(\mathrm{FEV}_{\mathbf{1 \cdot 0}}\right)$, age, smoking habits, and the number of years he had spent in his present department. In the second, the 114 working areas were divided into four sub-groups, according to defined levels of atmospheric pollution, and the prevalence of chronic bronchitis and mean $\mathrm{FEV}_{\mathbf{1 . 0}}$ in the four sub-groups was examined. In the third way, the mean atmospheric pollution levels in each of the 114 areas were related to the prevalence of bronchitis and to the mean $\mathrm{FEV}_{1 \cdot 0}$, age, and smoking habits in those areas.

The analysis demonstrates very clearly the over-riding importance of cigarette smoking in the aetiology of chronic bronchitis, but, so far as the main purpose of the survey is concerned, it is concluded that, if there is any relation between respiratory disability and atmospheric pollution in the two steel works, it is so slight that none of the three approaches to the problem was sensitive enough to detect it.

The implications of this are discussed in the light of the levels of pollution that were recorded in and around the two works.
\end{abstract}

There is now a considerable accumulation of evidence to indicate that urban atmospheric pollution plays an important part in the aetiology of chronic bronchitis (Pemberton and Goldberg, 1954; Pemberton, 1956; Fairbairn and Reid, 1958; Stocks, 1959; Buck and Brown, 1964; Angel, Fletcher, Hill, and Tinker, 1965; Holland and Reid, 1965). Because some men are exposed to high levels of atmospheric pollution at their places of work, one would expect to find good evidence that occupation is also implicated in the aetiology of the disease. There is some evidence of this type, but it is neither abundant nor conclusive.

Since 1964 the Department of Social and Occupational Medicine of the Welsh National School of Medicine, in an attempt to clarify this issue, has been engaged in an epidemiological study of respiratory symptomatology and lung function among the men 
employed in two large integrated steel works in South Wales. The project has been generously supported by the Nuffield Foundation. These two works appeared to be particularly suitable for a study of this type because they had very large and reasonably stable working populations which were distributed between a considerable number of clearly defined departments and working areas with widely differing kinds and degrees of atmospheric pollution (blast furnaces, coke ovens, converter and open hearth processes, hot mills, cold mills, tinplate, galvanizing, limestone quarries, etc.).

The two works are the Ebbw Vale Works of Richard Thomas and Baldwins Limited with a working population of about 9500 men and the Margam and Abbey Works of the Steel Company of Wales Limited with a working population of about 16500 men. Both now form part of the South Wales Group of the British Steel Corporation.

In the first paper we published in this series (Lowe, Pelmear, Campbell, Hitchens, Khosla, and King, 1968) we were concerned only with the ventilatory capacity, age, and physique of the non-bronchitic men in the two works populations. In the second paper (Warner, Davies, Jones, and Lowe, 1969), we described the distribution of sulphur dioxide and particulate atmospheric pollution in and around the two works. In this third paper we relate the data we have collected on the respiratory symptoms and lung function of the men to the measurements we have taken of the airborne particulate matter and atmospheric sulphur dioxide to which they were exposed.

\section{Material and methods}

A full description of the methods by which the information about respiratory symptomatology and lung function was collected is given in our first paper (Lowe et al., 1968). In brief, two teams of pre-clinical and other science students from the University of Wales were trained in small sub-groups to carry out the field work. The first team of 50 students helped with the field work at the Ebbw Vale Works for 13 days of the Easter vacation, 1964. The second team of 75 students helped at the Port Talbot Works (Margam and Abbey) for 20 days of the Easter vacation, 1965. During the surveys the two teams interviewed and examined 8081 men at Ebbw Vale and 10863 men at Port Talbot. The data collected from each of the men included respiratory symptoms recorded on the Medical Research Council Short Questionnaire (M.R.C. 1960), occupational, smoking and social histories, height and weight, and forced ventilatory output (recorded on a Garthur Vitalograph).

For the purpose of the present paper we have used the M.R.C. Questionnaire on Respiratory Symptoms to define five grades of symptomatology. We have called these grades: no respiratory symptoms; occasional symptoms; simple bronchitis; chronic bronchitis; and dyspnoea without bronchitis (Table 1). The five grades are defined as follows:
1. No respiratory symptoms. The subject answered 'No' to all the questions about winter cough, spells of increased cough and phlegm, absence from work because of chest illness and shortness of breath (i.e., 'No' to questions 1 and 3, 6 and 8,12a, 14b, and 21 in the M.R.C. questionnaire).

2. Occasional symptoms. Although the subject had some symptoms he did not have persistent cough and phlegm for as much as three months each year and he was not short of breath ('Yes' to 1 and/or 3, 6, 8, 12a, and 21, but 'No' to 5,10 , and $14 \mathrm{~b}$ ).

3. Simple bronchitis. The subject had persistent cough and phlegm but no complications, i.e., spells of increased cough, absence from work, shortness of breath ('Yes' to 5 and 10 , but 'No' to $12 \mathrm{a}, 14 \mathrm{~b}$, and 21 ).

4. Chronic bronchitis. The subject had persistent cough and phlegm with one or more of the three complications ('Yes' to 5 and 10 and 'Yes' to $12 \mathrm{a}$ and/or 14b and/or 21).

5. Dyspnoea without bronchitis. This anomalous group of subjects had shortness of breath without persistent cough and phlegm ('Yes' to $14 \mathrm{~b}$, but 'No' to 5 and 10 ).

\section{TABLE 1}

DisTRIBUTION OF RESPIRATORY SYMPTOMS AMONG Men Aged 20-64 Years in the Two Steel WorKS

\begin{tabular}{|c|c|c|}
\hline & \multicolumn{2}{|c|}{ Percentage distribution } \\
\hline & Ebbw Vale & Port Talbot \\
\hline 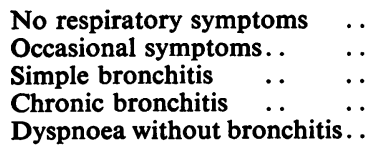 & $\begin{array}{r}40 \cdot 7 \\
26 \cdot 7 \\
11 \cdot 0 \\
15 \cdot 0 \\
6 \cdot 6\end{array}$ & $\begin{array}{r}46 \cdot 3 \\
24 \cdot 4 \\
11 \cdot 4 \\
13 \cdot 8 \\
4 \cdot 2\end{array}$ \\
\hline (No. of men) .. & $\begin{array}{c}100 \\
\left(\begin{array}{c}7 \\
291\end{array}\right)\end{array}$ & $\begin{array}{c}100 \\
(10484)\end{array}$ \\
\hline
\end{tabular}

The Garthur Vitalograph gives a permanent tracing of forced ventilatory output. Each man was allowed one practice blow on the instrument and then two definitive tracings were made. We are concerned here only with forced expiratory volume at one second $\left(\mathrm{FEV}_{1.0}\right)$ and the data we present refer to the higher of the two recorded values.

The sampling techniques and the instruments used to measure airborne particulate matter and atmospheric sulphur dioxide are described in the second paper (Warner et al., 1969). Briefly, within the works the atmospheric concentrations of respirable and nonrespirable dusts were measured with standard Hexhlet samplers and of sulphur dioxide with Drechsel bubblerbottles containing a solution of hydrogen peroxide. Samples were taken at 552 sites (252 at the Ebbw Vale works and 300 at the Port Talbot works). Over a period of three years we took 752 samples for the estimation of particulate matter (with a total sampling time of 23684 hours) and 1366 samples for the estimation of sulphur dioxide (with a totalsampling time of 22571 hours). Over the same period sulphur dioxide and smoke density were continuously monitored by means of the standard instrument developed by the Warren Spring Laboratory 
(Ministry of Technology, 1961) from four sites in the town of Ebbw Vale and from seven sites in Port Talbot.

In the examination of the relation between atmospheric pollution and respiratory disability (measured in terms of respiratory symptomatology and $F E V_{1.0}$ ), we have limited ourselves to 114 clearly defined working areas (52 at Ebbw Vale and 62 at Port Talbot) for each of which we had measurements of atmospheric sulphur dioxide and of the respirable fraction of the airborne particulate matter. Examples of these areas are: the frontside, materials handling, stoves, and gas plant areas of the blast furnace departments; the stage, teaming, mixer, lime plant, mould preparation plant, and continuous casting areas of the steel plant; and the ovens, byproducts, coke handling, and coal handling areas of the coke oven departments. Many men move around from area to area or even from department to department during their working day, so for this part of the analysis we have included only those men who spent the greater part of their working time within one of the defined working areas (4 506 men at Ebbw Vale and 5943 men at Port Talbot).

\section{The results}

The two works populations were different, amongst other things, in their age distributions, physique, and smoking habits (Lowe et al., 1968). They have therefore been kept separate in the presentation of results.

\section{Age and smoking habits}

As would be expected, our data underline the need to take into account age and smoking habits in any epidemiological study of respiratory symptomatology or lung function. Table 2 gives the prevalence of chronic bronchitis in the two works by age and smoking habits. For each age group, and in both works, chronic bronchitis was much commoner among current smokers than among men who had never smoked, and its prevalence increased with the amount smoked, the ex-smokers usually occupying a position intermediate between the light smokers and those who had never smoked. Also for each smoking category (including ex-smokers and those who had never smoked) the prevalence of chronic bronchitis increased steeply with age. In general terms, for each age group heavy smokers (25 or more cigarettes a day) were about three times more likely to suffer from chronic bronchitis than nonsmokers, and for each smoking category elderly men (55-64 years of age) were four or five times more likely to suffer than young men (20-24). The effect of smoking was so pronounced that the young men who smoked more than 25 cigarettes a day had as much bronchitis as the middle-aged men (45-54) who had never smoked.

We found that ventilatory output was related in much the same way as respiratory symptomatology to age and smoking habits (Table 3). Mean FEV 1.0 declined regularly with age and at each age group was lower for smokers than for non-smokers and lower for heavy smokers than for light smokers. At Port Talbot, for example, in the age group 55-64 the men who smoked 25 or more cigarettes a day had a mean $\mathrm{FEV}_{1.0}$ of 2.38 litres, while those who had never smoked had an $\mathrm{FEV}_{1.0}$ of 2.89 litres $-\mathbf{a}$ difference of half a litre. In other words, among these older men heavy smoking reduced forced expiratory volume by almost $20 \%$.

Table 4 shows the distribution of respiratory symptoms among older men aged 55-64 in relation to their smoking habits, to make the point that important as age and smoking are in the aetiology of chronic bronchitis, they are not the only factors. This is evident because, first, chronic bronchitis was not uncommon among elderly men who had never

TABLE 2

Percentage of Men with Chronic Bronchitis related to Age and Smoking Habits

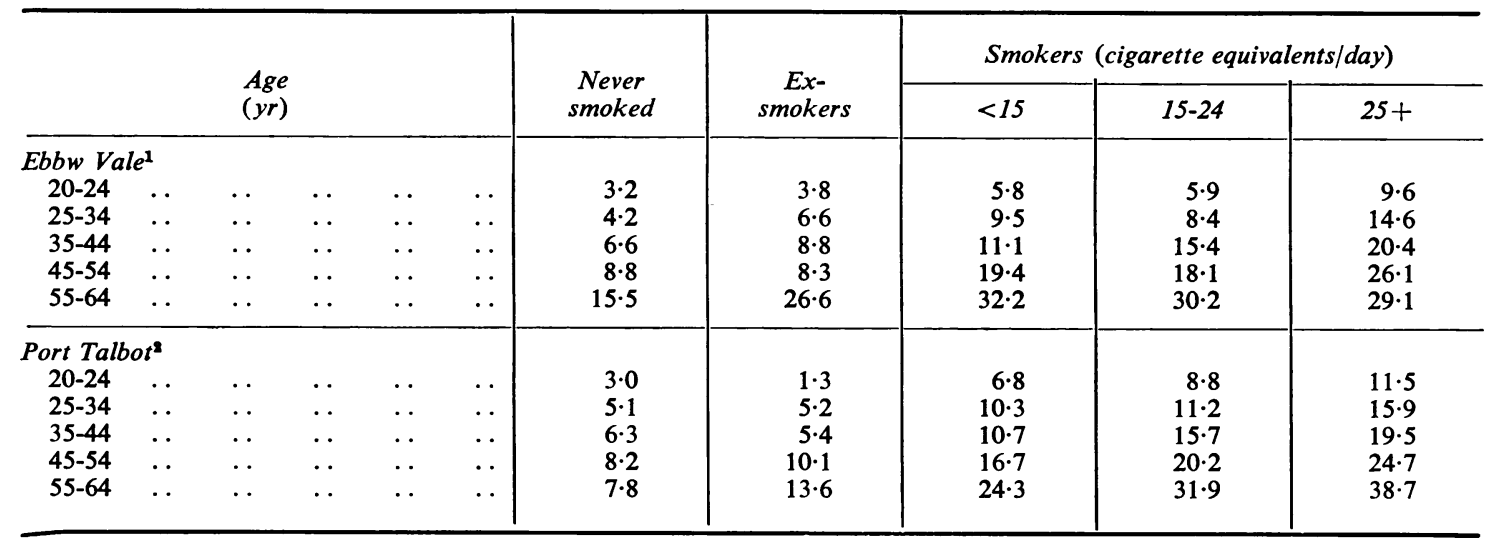


TABLE 3

Mean FEV $_{1 \cdot 0}$ (Litres) Related to Age and Smoking Habits

\begin{tabular}{|c|c|c|c|c|c|c|c|c|c|c|}
\hline & & & & & & & & Smo & rette eq & day) \\
\hline & & & & & & & & $<15$ & $15-24$ & $25+$ \\
\hline $\begin{array}{c}\text { Ebbw Vale } \\
20-24 \\
25-34 \\
35-44 \\
45-54 \\
55-64\end{array}$ & $\begin{array}{l}e \\
\ldots \\
\cdots \\
\cdots \\
\cdots\end{array}$ & $\begin{array}{l}\cdots \\
\cdots \\
\cdots \\
\cdots\end{array}$ & $\begin{array}{l}\cdots \\
\cdots \\
\cdots \\
\cdots\end{array}$ & $\begin{array}{l}\cdots \\
\cdots \\
\cdots \\
\cdots\end{array}$ & $\begin{array}{l}. \\
\cdots \\
\cdots \\
\cdots \\
.\end{array}$ & $\begin{array}{l}4.19 \\
4.01 \\
3.42 \\
2.95 \\
2.65\end{array}$ & $\begin{array}{l}4.24 \\
3.95 \\
3.48 \\
3.00 \\
2.38\end{array}$ & $\begin{array}{l}4 \cdot 24 \\
3.95 \\
3 \cdot 39 \\
2 \cdot 84 \\
2 \cdot 37\end{array}$ & $\begin{array}{l}4 \cdot 17 \\
3 \cdot 86 \\
3 \cdot 34 \\
2 \cdot 80 \\
2 \cdot 35\end{array}$ & $\begin{array}{l}4.14 \\
3.75 \\
3.29 \\
2.85 \\
2.32\end{array}$ \\
\hline $\begin{array}{c}\text { Port Talbo } \\
20-24 \\
25-34 \\
35-44 \\
45-54 \\
55-64\end{array}$ & $\begin{array}{l}t \\
\ldots \\
\ldots \\
\ldots \\
\ldots\end{array}$ & $\begin{array}{l}\cdots \\
\cdots \\
\therefore \\
.\end{array}$ & $\begin{array}{l}\cdots \\
\cdots \\
\cdots \\
\cdots\end{array}$ & $\begin{array}{l}\because \\
\ddot{ } \\
\because \\
\cdots\end{array}$ & $\begin{array}{l}\cdots \\
\cdots \\
\cdots \\
\cdots\end{array}$ & $\begin{array}{l}4.44 \\
4 \cdot 16 \\
3.74 \\
3.28 \\
2.89\end{array}$ & $\begin{array}{l}4.48 \\
4 \cdot 12 \\
3.70 \\
3 \cdot 18 \\
2.67\end{array}$ & $\begin{array}{l}4.44 \\
4.13 \\
3.60 \\
3.09 \\
2.54\end{array}$ & $\begin{array}{l}4.34 \\
4.00 \\
3.49 \\
3.01 \\
2.47\end{array}$ & $\begin{array}{l}4.29 \\
3.94 \\
3.46 \\
2.90 \\
2.38\end{array}$ \\
\hline
\end{tabular}

smoked $(15 \cdot 5 \%$ of the men aged 55-64 at Ebbw Vale and $7.8 \%$ at Port Talbot), and second, a substantial proportion of elderly smokers were not only free from bronchitis but affirmed that they were free from all respiratory symptoms $(20.7 \%$ of the elderly men at Ebbw Vale and $27 \cdot 1 \%$ at Port Talbot).

\section{Atmospheric pollution at place of work}

With the knowledge that age and smoking habits are major factors in determining forced expiratory volume and the presence of respiratory symptoms, we now turn to investigate the extent to which respiratory disability among 4506 men at Ebbw Vale and 5943 men at Port Talbot who spent most of their working hours in one or other of the 114 defined working areas was related to the levels of atmospheric pollution to which they were exposed. We have explored this problem in three different ways.
In the first instance we assigned to each of the men the mean value of sulphur dioxide and respirable dust for the area in which he was known to be working and related this to his ventilatory capacity $\left(F V_{1 \cdot 0}\right)$, his age, the number of years he had spent in that works department, and the number of cigarettes he was smoking per day (pipe and cigar tobacco was converted into cigarette equivalents). The zero order correlations are given in Table 5. It shows that at Ebbw Vale FEV $_{1.0}$ was correlated negatively in descending order of magnitude with age, years in the department, cigarette equivalents/ day, sulphur dioxide, and respirable dust. Because of the large numbers of men involved (4 506) all of these correlations are statistically significant at the $1 \%$ level. The correlations with pollutants are so low that they are of little practical importance. At Port Talbot with rather more men (5943) FEV $_{1.0}$ was correlated negatively at the $1 \%$ level with age, years

TABLE 4

Distribution of Respiratory SyMPtoms In Relation to SMOKING Habits AMONG Men Aged 55-64 YeARS

\begin{tabular}{|c|c|c|c|c|c|c|c|c|}
\hline & & & \multicolumn{6}{|c|}{ Percentage distribution } \\
\hline & & & \multicolumn{3}{|c|}{ Ebbw Vale } & \multicolumn{3}{|c|}{ Port Talbot } \\
\hline & & & $\begin{array}{c}\text { Never } \\
\text { smoked }\end{array}$ & Ex-smoker & Smoker & $\begin{array}{c}\text { Never } \\
\text { smoked }\end{array}$ & Ex-smoker & Smoker \\
\hline $\begin{array}{l}\text { No respiratory symptoms } \\
\text { Occasional symptoms } \\
\text { Simple bronchitis } \quad . \\
\text { Chronic bronchitis . . } \\
\text { Dyspnoea without bronchitis }\end{array}$ & $\begin{array}{l}\cdots \\
\cdots \\
\cdots \\
\cdots\end{array}$ & $\begin{array}{l}\cdots \\
\cdots \\
\cdots \\
\cdots \\
\cdots\end{array}$ & $\begin{array}{r}57 \cdot 7 \\
22 \cdot 7 \\
1 \cdot 0 \\
15 \cdot 5 \\
3 \cdot 1\end{array}$ & $\begin{array}{r}35 \cdot 1 \\
21 \cdot 8 \\
4 \cdot 4 \\
26 \cdot 6 \\
12 \cdot 1\end{array}$ & $\begin{array}{l}20 \cdot 7 \\
25 \cdot 5 \\
11 \cdot 1 \\
30 \cdot 7 \\
12 \cdot 0\end{array}$ & $\begin{array}{r}59 \cdot 3 \\
18 \cdot 5 \\
4 \cdot 8 \\
7 \cdot 8 \\
9 \cdot 6\end{array}$ & $\begin{array}{r}46 \cdot 7 \\
20 \cdot 8 \\
6 \cdot 0 \\
13 \cdot 6 \\
13 \cdot 0\end{array}$ & $\begin{array}{r}27 \cdot 1 \\
23 \cdot 2 \\
12 \cdot 0 \\
30 \cdot 2 \\
7 \cdot 5\end{array}$ \\
\hline $\begin{array}{lll}\text { Total } & \ldots & \ldots \\
\text { (No. of men) } & \ldots & \ldots\end{array}$ & $\begin{array}{l}. \\
\cdots\end{array}$ & $\ddot{.}$ & $\begin{array}{l}100 \\
(97)\end{array}$ & $\begin{array}{c}100 \\
(248)\end{array}$ & $\begin{array}{c}100 \\
(981)\end{array}$ & $\begin{array}{c}100 \\
(167)\end{array}$ & $\begin{array}{c}100 \\
(332)\end{array}$ & $\begin{array}{c}100 \\
(1034)\end{array}$ \\
\hline
\end{tabular}


TABLE 5

Correlations between FEV $1 \cdot 0$, Age, Cigarette Equivalents, Years in Department, Respirable Dust Concentration, and SulPhur Dioxide

\begin{tabular}{|c|c|c|c|c|c|c|c|}
\hline & & & Age & $\begin{array}{c}\text { Cigarette } \\
\text { equivalents } \\
\text { per day }\end{array}$ & $\begin{array}{c}\text { Years in } \\
\text { department }\end{array}$ & Dust & $\mathrm{SO}_{2}$ \\
\hline 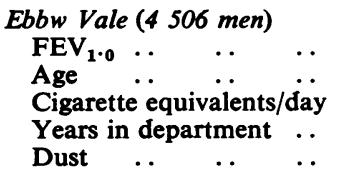 & $\begin{array}{l}\cdots \\
\cdots \\
\cdots \\
\cdots\end{array}$ & $\begin{array}{l}\cdots \\
\cdots \\
\cdots \\
\cdots\end{array}$ & $\begin{array}{c}-0.6630^{*} \\
1.0\end{array}$ & $\begin{array}{c}-0.1340^{*} \\
0.1364^{*} \\
1.0\end{array}$ & $\begin{array}{c}-0.4115^{*} \\
0.6275^{*} \\
0.0780^{*} \\
1.0\end{array}$ & $\begin{array}{l}-0.0619^{*} \\
0.0801^{*} \\
0.0309 \\
0.0808^{*} \\
1.0\end{array}$ & $\begin{array}{r}-0.0716^{*} \\
0.0731^{*} \\
0.0563^{*} \\
0.0724^{*} \\
0.0437^{*}\end{array}$ \\
\hline 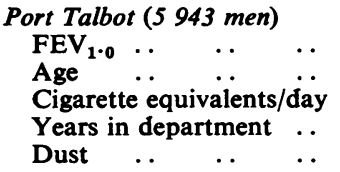 & $\begin{array}{l}. \\
\cdots \\
\cdots \\
\cdots\end{array}$ & $\begin{array}{l}\ldots \\
\cdots \\
\cdots \\
\cdots\end{array}$ & $\begin{array}{c}-0.6579^{*} \\
1.0\end{array}$ & $\begin{array}{c}-0.1592^{*} \\
0.0894^{*} \\
1.0\end{array}$ & $\begin{array}{c}-0.2480^{*} \\
0.4236^{*} \\
0.0375^{*} \\
1.0\end{array}$ & $\begin{array}{l}-0.0289 \\
0.0566^{*} \\
0.0763^{*} \\
0.0888^{*} \\
1.0\end{array}$ & $\begin{array}{r}0.0045 \\
-0.0059 \\
0.0097 \\
0.0370^{*} \\
0.2121^{*}\end{array}$ \\
\hline
\end{tabular}

* Significant at $1 \%$

in department, and cigarette equivalents but not with respirable dust or sulphur dioxide.

However, we cannot take even the low zero order correlations with FEV $_{1.0}$ at their face value as there were significant zero order correlations between some of the other variables which are known to

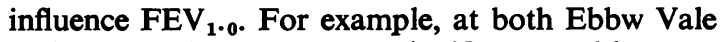
and Port Talbot there were significant positive correlations for respirable dust with age and years in department and for sulphur dioxide with years in department, and at Ebbw Vale for sulphur dioxide with age and cigarettes. This means that men exposed to higher concentrations of dust and sulphur dioxide tended to be older, to have stayed longer in the same department, and to have smoked more than those exposed to lower concentrations.

Consequently it was considered necessary to adjust the correlations shown in Table 5. This was done, and it was found that none of the second order partial correlations for $\mathrm{FEV}_{1 \cdot 0}$ with sulphur dioxide and respirable dust (holding age and cigarette equivalents constant) was significant at even the $5 \%$ level. Apparently the low but significant correlations between $F_{E V} \cdot 0$ and atmospheric pollution are attributable to the greater age and heavier smoking habits of the men working in the areas of high pollution.

Our second approach to the problem was to divide the defined working areas into four sub-groups: (1) those with low levels of both respirable dust and sulphur dioxide; (2) those with low dust and high sulphur dioxide; (3) those with high dust and low sulphur dioxide; and (4) those with high levels of both respirable dust and sulphur dioxide. For this purpose we classified a working area as having a low respirable dust level if the mean of the samples taken in that area was less than $1 \mathrm{mg} / \mathrm{m}^{3}$ and a low $\mathrm{SO}_{2}$ if the mean was below $1000 \mu \mathrm{g} / \mathrm{m}^{3}$. Areas with mean measurements above these values were arbitrarily classified as having high levels of pollution, 'arbitrarily' because the values were very much lower than the generally accepted maximum allowable concentration (MAC) (see Discussion). The prevalence of chronic bronchitis (as defined) and the mean $\mathrm{FEV}_{1.0}$ in those four areas were then compared (Table 6). There is some indication that the prevalence of chronic bronchitis is a little higher and the mean $\mathrm{FEV}_{1.0}$ a little lower in the areas of high pollution. But in those areas the mean age and number of cigarettes smoked also tended to be higher (confirming the correlations in Table 5).

To correct for this we calculated the 'expected' value for the mean $\mathrm{FEV}_{1 \cdot 0}$, making allowance for the mean age, height, and smoking habits of the men in each of the four groups of areas. Student's $t$ tests showed that the difference between the actual and expected values for $\mathrm{FEV}_{1.0}$ was not statistically significant at either works. This indicates once again that the apparently higher prevalence of chronic bronchitis and lower FEV $_{1.0}$ in the areas of high pollution was attributable to the greater age and heavier smoking habits of the men in those areas.

In our third approach to the problem we used the same mean values of the levels of atmospheric pollution for each of the working areas that we had used in the first method. But this time, instead of relating

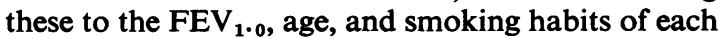
man (4506 at Ebbw Vale and 5943 at Port Talbot), we related them to the means of those variables for each of the working areas (52 at Ebbw Vale and 62 at Port Talbot). By doing this we were also able to include in the correlation table the percentage of 
TABLE 6

Percentage of Men with Chronic Bronchitis and Mean FEV F.0 $_{1 N}$ Working AREas of Low AND High Atmospheric Pollution

\begin{tabular}{|c|c|c|c|c|}
\hline & \multicolumn{4}{|c|}{ Level of pollution } \\
\hline & $\begin{array}{c}\text { Low } \\
\text { dust } \\
\text { low } \mathrm{SO}_{2}\end{array}$ & $\begin{array}{l}\text { Low } \\
\text { dust } \\
\text { high } \\
\mathrm{SO}_{2}^{*}\end{array}$ & $\begin{array}{c}\text { High } \\
\text { dust } \\
\text { low } \mathrm{SO}_{2}\end{array}$ & $\begin{array}{c}\text { High } \\
\text { dust } \\
\text { high } \\
\mathrm{SO}_{2}\end{array}$ \\
\hline $\begin{array}{l}\text { Ebbw Vale } \\
\text { No. of men.. } \\
\% \text { with chronic } \\
\text { bronchitis } \\
\text { Mean FEV } \\
\text { Mean age (years).. } \\
\text { Mean cigarette } \\
\text { equivalents/day.. } \\
\text { Mean years in dept. } \\
\text { Mean height (inches) }\end{array}$ & \begin{tabular}{|c|}
3766 \\
\\
$13 \cdot 7$ \\
3.42 \\
$38 \cdot 6$ \\
\\
$12 \cdot 3$ \\
$10 \cdot 7$ \\
$67 \cdot 4$
\end{tabular} & $\begin{array}{c}612 \\
14 \cdot 9 \\
3 \cdot 21 \\
41 \cdot 7 \\
\\
13 \cdot 9 \\
13 \cdot 0 \\
67 \cdot 3\end{array}$ & $\begin{array}{l}83 \\
10 \cdot 8 \\
3 \cdot 07 \\
42 \cdot 5 \\
14 \cdot 2 \\
13 \cdot 1 \\
67 \cdot 0\end{array}$ & $\begin{array}{l}45 \\
\\
17 \cdot 8 \\
3 \cdot 08 \\
43 \cdot 1 \\
\\
14 \cdot 8 \\
12 \cdot 4 \\
66 \cdot 9\end{array}$ \\
\hline $\begin{array}{l}\text { Port Talbot } \\
\text { No. of men. . . } \\
\% \text { with chronic } \\
\text { bronchitis } \ldots \\
\text { Mean FEV } \\
\text { Mean age (years) .. } \\
\text { Mean cigarette equi- } \\
\text { valents/day ... } \\
\text { Mean years in dept. } \\
\text { Mean height (inches) }\end{array}$ & \begin{tabular}{|c}
4729 \\
$12 \cdot 5$ \\
$3 \cdot 49$ \\
$41 \cdot 4$ \\
\\
$10 \cdot 4$ \\
$9 \cdot 6$ \\
$67 \cdot 5$
\end{tabular} & & $\begin{array}{c}939 \\
\\
13 \cdot 1 \\
3 \cdot 43 \\
42 \cdot 3 \\
12 \cdot 7 \\
9 \cdot 8 \\
67 \cdot 3\end{array}$ & $\begin{array}{l}275 \\
15 \cdot 3 \\
3 \cdot 47 \\
41 \cdot 3 \\
\\
11 \cdot 7 \\
11 \cdot 1 \\
67 \cdot 4\end{array}$ \\
\hline
\end{tabular}

Low dust $<1 \mathrm{mg} / \mathrm{m}^{3}$.

Low $\mathrm{SO}_{2}<1000 \mu \mathrm{g} / \mathrm{m}^{3}$.

*At Port Talbot there was no works area with low dust and high $\mathrm{SO}_{2}$ as defined.

TABLE 7

Zero Order Correlations between Mean Atmospheric Pollution in Each of the Defined Areas and the Percentage of Men with Chronic Bronchitis AND the MEAN Values for FEV $_{1.0}$,

Age, and Cigarette Equivalents IN THE Corresponding Areas

\begin{tabular}{|c|c|c|c|c|}
\hline & \multicolumn{2}{|c|}{$\begin{array}{l}\text { Ebbw Vale } \\
52 \text { defined } \\
\text { working areas }\end{array}$} & \multicolumn{2}{|c|}{$\begin{array}{c}\text { Port Talbot } \\
62 \text { defined } \\
\text { working areas }\end{array}$} \\
\hline & $\begin{array}{c}\text { Mean } \\
\text { respir- } \\
\text { able dust }\end{array}$ & $\begin{array}{c}\text { Mean } \\
\mathrm{SO}_{2}\end{array}$ & $\begin{array}{c}\text { Mean } \\
\text { respir- } \\
\text { able dust }\end{array}$ & $\begin{array}{c}\text { Mean } \\
\mathrm{SO}_{2}\end{array}$ \\
\hline 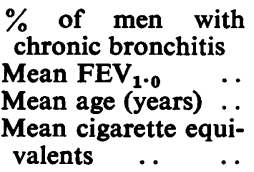 & $\begin{array}{r}0.0860 \\
-0.2436 \\
0.3017 \\
0.0988\end{array}$ & $\begin{array}{r}0.1956 \\
-0.2432 \\
0.1824 \\
\\
0.2974\end{array}$ & $\begin{array}{r}0.1494 \\
-0.1215 \\
0.2028 \\
0.4861\end{array}$ & $\begin{array}{r}0.0985 \\
0.0230 \\
-0.0209 \\
0.0614\end{array}$ \\
\hline
\end{tabular}

For 50 degrees of freedom: 0.354 is significant at the $1 \%$ level $: 0.273$ is significant at the $5 \%$ level. men with chronic bronchitis as a variable for each area. The zero order correlations given in Table 7 are weighted for the number of men in the areas. For dust and sulphur dioxide there was a negative correlation with FEV $_{1.0}$ (as in the first method) and a positive correlation with chronic bronchitis (as in the second method). But now even the zero order correlations between $\mathrm{FEV}_{1 \cdot 0}$ and the atmospheric pollutants are not significant at the $5 \%$ level despite significant correlations for one of the pollutants with age or cigarettes.

We can only conclude from this analysis that if there is a relationship between respiratory disability and atmospheric pollution among the men in the two works it is very slight and none of our three approaches to the problem was sensitive enough to detect it.

\section{Discussion}

Data on occupational mortality in Part II of the Registrar General's Decennial Supplement on the Census of 1951 (Registrar General, 1958), although not easy to interpret, point to a relationship between mortality from bronchitis and exposure to atmospheric pollutants at work (Lowe, 1969). But attempts to demonstrate by epidemiological methods an association between the prevalence of respiratory symptoms and the intensity of exposure to dust or sulphur dioxide in particular occupations have for the most part been either negative or unconvincing (Paul, 1961; Brinkman and Coates, 1962; Skalpe, 1964; Ferris, Burgess, and Worcester, 1967). Although chronic bronchitis has been shown to be about three times more common among coal-miners than among non-miners of comparable age and social class (Pemberton, 1956; Higgins, Oldham, Cochrane, and Gilson, 1956), even the most careful studies of miners have been unable to demonstrate any clear association between their respiratory symptomatology and the degree to which they have been exposed to coal dust (Higgins and Cochrane, 1961 ; Hyatt, Kistin, and Mahan, 1964; Sluis-Cremer, Walters, and Sichel, 1967).

In this, the third part of our large-scale study of the distribution and determinants of chronic bronchitis among the men employed in two integrated steelworks, we have attempted to find a relation between respiratory symptomatology and ventilatory capacity of the men and the atmospheric pollutants to which they had been exposed. The attempt has failed, although we have certainly demonstrated, once again, the over-riding importance of cigarette smoking in the aetiology of chronic bronchitis. We must emphasize that our failure to show any association between the distribution of bronchitis and the distribution of atmospheric pollution in the two works does not necessarily mean that the pollu- 
tion to which some of the men with bronchitis had been exposed had played no part in the genesis of their disability. It does mean, however, that the part played, if any, was so small that it was obscured by other factors.

In addition to the masking effect of age and smoking habits, many other difficulties stood in the way of relating respiratory symptomatology and ventilatory capacity to atmospheric pollution. In the first place, chronic bronchitis takes many years to develop and we are not sure how the current measurements of dust and sulphur dioxide that we have taken relate to past levels of pollution, although we were told by knowledgeable people that they had probably not changed much during the last 15 years. Then, our measurements were taken at fixed points, and even those men who worked within a clearly defined area moved around a great deal within that area during the shift. However, for reasons we have given elsewhere (Warner et al., 1969), we believe that the mean levels of pollution used in our analysis were satisfactory indices of shift exposure. In addition, there are the problems posed by an indeterminate amount of selection into and out of the different occupations and different working areas. For example, jobs making heavy demands tend to recruit men who are fitter and physically stronger than average, and some of the jobs which expose the men working in them to high levels of pollution are of this nature. It is also likely that men who find they are sensitive to dust or fumes, or are beginning to develop respiratory symptoms, will tend to move away from the more polluted areas. All these and other factors would tend to dilute an association between respiratory disability and current exposure to atmospheric pollution, and, if the association is weak, to hide it altogether.

Nevertheless, the lack of association between respiratory disability and atmospheric sulphur dioxide is unexpected. In some working areas, particularly those around the blast furnaces (Table 8), the mean concentration of sulphur dioxide from the 24-hour samples was about five times greater than the winter mean for the City of London, and on some occasions the highest single 24-hour samples taken at the front side of blast furnaces were four times greater than the highest measurement recorded in the London smog of 1952.

Sulphur dioxide is certainly a lung irritant (Greenwald, 1954) but our investigation adds some weight to the suspicion that, so far as chronic bronchitis is concerned, it may not be the most harmful component of urban pollution (Lawther, Martin, and Wilkins, 1962). It also indicates that the recommended MAC of $13000 \mu \mathrm{g} / \mathrm{m}^{3}$ (Ministry of Labour, 1966) for 8 hours' industrial exposure, although probably too high, is not as unreasonably high as some of us had previously believed.
TABLE 8

AtMOSPHERIC CONCENTRATIONS OF $\mathrm{SO}_{2}$ AROUND
BLAST FurNaCES

\begin{tabular}{|c|c|c|}
\hline Blast furnaces & & $\underset{\left(\mu g / \mathbf{m}^{2}\right)}{\mathrm{SO}_{2}}$ \\
\hline 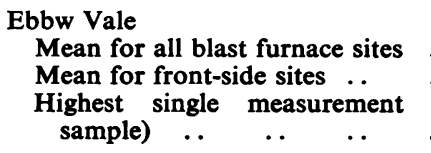 & 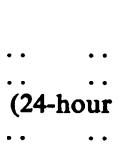 & $\begin{array}{r}1761 \\
3224 \\
17442\end{array}$ \\
\hline 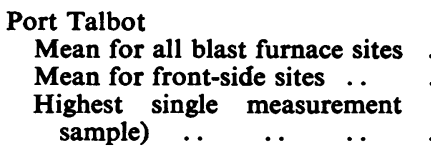 & $\begin{array}{l}\cdots \\
\ddot{(24-h o u r} \\
\cdots\end{array}$ & $\begin{array}{r}1514 \\
2149 \\
13129\end{array}$ \\
\hline $\begin{array}{l}\text { London } \\
\text { Winter mean, City of London (19 } \\
\text { Highest measurement, London } \\
1952 \text { (Ministry of Technology, }\end{array}$ & $\begin{array}{ll}966) & \\
\text { smog } & \text { of } \\
1967) & \ldots\end{array}$ & $\begin{array}{r}384 \\
3490\end{array}$ \\
\hline $\begin{array}{l}\text { MAC for } 8 \text { hours' industrial } \\
\text { (Ministry of Labour, 1966) }\end{array}$ & $\begin{array}{l}\text { exposure } \\
\ldots \quad \ldots\end{array}$ & 13000 \\
\hline
\end{tabular}

In retrospect, our failure to show an association between respiratory disability and the airborne dust in the two works is not surprising, for the measurements of respirable particulate matter were much lower than we had anticipated. The working areas yielding the highest levels of airborne dust were those around the blast furnaces and coke ovens (Table 9), but even there the respirable fraction never exceeded a mean level of $2 \mathrm{mg} / \mathrm{m}^{3}$. We made a few qualitative examinations of the respirable fraction of the airborne dust in different parts of the works by $x$-ray diffraction (using powder camera and diffractometer techniques). The dust proved to be almost entirely inert; it was compounded of haematite $\left(\mathrm{Fe}_{2} \mathrm{O}_{3}\right)$, magnetite $\left(\mathrm{Fe}_{3} \mathrm{O}_{4}\right)$, and calcium sulphate $\left(\mathrm{CaSO}_{4}\right)$. The recommended MAC for iron oxide fumes and the respirable fraction of coal dust is, at present, $10 \mathrm{mg} / \mathrm{m}^{3}$, well above the levels we recorded.

Steel towns have a bad reputation for atmospheric pollution. It is of interest, therefore, to compare the mean daily concentration of sulphur dioxide and the smoke density index at the two most polluted measuring sites in the towns of Port Talbot and Ebbw Vale with the measurements from towns with better reputations (Table 10). So far as sulphur dioxide is concerned, the bad reputation of the two steel towns is unwarranted. They are no worse than Cardiff, which is a particularly clean town, better than Harrogate (quite a clean town), and a great deal better than London. Even so far as smoke density is concerned, Ebbw Vale is no worse than Harrogate, and Port Talbot is appreciably better. Undoubtedly, 
TABLE 9

Airborne Particulate Matter around Blast Furnaces AND COKe Ovens

\begin{tabular}{|c|c|c|c|}
\hline & & $\begin{array}{c}\text { Respirable } \\
\left(\mathrm{mg} / \mathrm{m}^{3}\right)\end{array}$ & $\begin{array}{c}\text { Non- } \\
\text { respirable } \\
\left(\mathrm{mg} / \mathrm{m}^{3}\right)\end{array}$ \\
\hline $\begin{array}{l}\text { Ebbw Vale } \\
\text { Blast furnaces } \\
\text { Mean for all sites } \\
\text { Mean for front-side sites } \\
\text { Coke ovens } \\
\begin{array}{l}\text { Mean for all sites } \\
\text { Mean for ovens }\end{array} \quad \ldots\end{array}$ & $\begin{array}{l}\ldots \\
\cdots \\
\cdots \\
\cdots\end{array}$ & $\begin{array}{l}1.0 \\
1.8 \\
\\
1.3 \\
0.6\end{array}$ & $\begin{array}{r}4 \cdot 6 \\
9 \cdot 6 \\
\\
7 \cdot 2 \\
15 \cdot 7\end{array}$ \\
\hline $\begin{array}{l}\text { Port Talbot } \\
\text { Blast furnaces } \\
\text { Mean for all sites } \\
\text { Mean for front-side sites } \\
\text { Coke ovens } \\
\begin{array}{l}\text { Mean for all sites } \\
\text { Mean for ovens }\end{array} \quad \text {. }\end{array}$ & $\begin{array}{l}\cdots \\
\cdots \\
\cdots \\
\cdots\end{array}$ & $\begin{array}{l}0.9 \\
1 \cdot 3 \\
1 \cdot 0 \\
1 \cdot 7\end{array}$ & $\begin{array}{l}1 \cdot 5 \\
2 \cdot 1 \\
4 \cdot 1 \\
7 \cdot 1\end{array}$ \\
\hline 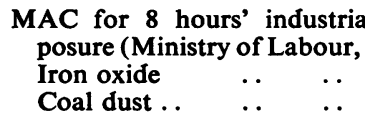 & $\begin{array}{c}\text { ex- } \\
\text { 66) } \\
\cdots \\
\cdots\end{array}$ & $\begin{array}{l}10 \cdot 0 \\
10 \cdot 0\end{array}$ & \\
\hline
\end{tabular}

however, the steel towns are dirty places to live in (Table 11). The amount of grit per square mile deposited in them is greater than in London, and very much greater than in Harrogate or in Cardiff.

To conclude, we would reiterate that our survey has demonstrated, once again, the overwhelming importance of cigarette smoking as a cause of

TABLE 10

Atmospheric Sulphur Dioxide and SMOKe Density INDEX IN TWO STEEL TOWNS COMPARED WITH Certain Other TOWNS

\begin{tabular}{|c|c|c|c|c|}
\hline & \multicolumn{4}{|c|}{$\begin{array}{c}\text { Mean daily measurements }\left(\mu \mathrm{g} / \mathrm{m}^{3}\right) \\
\text { year ended March } 1966\end{array}$} \\
\hline & \multicolumn{2}{|c|}{$\mathrm{SO}_{2}$ concentration } & \multicolumn{2}{|c|}{$\begin{array}{l}\text { Smoke density } \\
\text { index }\end{array}$} \\
\hline & Winter & Summer & Winter & Summer \\
\hline 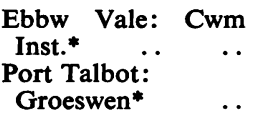 & $\begin{array}{l}67 \\
80\end{array}$ & $\begin{array}{l}34 \\
63\end{array}$ & $\begin{array}{l}77 \\
29\end{array}$ & $\begin{array}{l}39 \\
21\end{array}$ \\
\hline $\begin{array}{l}\text { London City: St. } \\
\text { Paul's } . . \\
\text { Harrogate: } \\
\text { Municipal Offices } \\
\text { Cardiff: City Centre }\end{array}$ & $\begin{array}{r}137 \\
57\end{array}$ & $\begin{array}{l}57 \\
35\end{array}$ & $\begin{array}{r}106 \\
38\end{array}$ & $\begin{array}{l}23 \\
33 \\
23\end{array}$ \\
\hline
\end{tabular}

* These were the sites which generally gave the highest measurements in the two towns.
TABLE 11

Undissolved Deposition (Grit) in Two Steel TOWNS COMPared with Certain Other TOWNS (tons per square mile per calendar month)

\begin{tabular}{|c|c|c|c|c|c|}
\hline \multirow{3}{*}{\multicolumn{2}{|c|}{ Town and site }} & \multicolumn{4}{|c|}{$\begin{array}{c}\text { Undissolved deposition, }{ }^{*} \text { year } \\
\text { ended }\end{array}$} \\
\hline & & \multicolumn{2}{|c|}{ March 1966} & \multicolumn{2}{|c|}{ March 1967} \\
\hline & & Winter & Summer & Winter & Summer \\
\hline $\begin{array}{l}\text { Ebbw Vale } \\
\text { Port Talbot }\end{array}$ & $\begin{array}{l}\cdots \\
\cdots\end{array}$ & $\begin{array}{l}55 \cdot 8 \\
39 \cdot 0\end{array}$ & $\begin{array}{l}40 \cdot 3 \\
37 \cdot 6\end{array}$ & $\begin{array}{l}30 \cdot 3 \\
26 \cdot 6\end{array}$ & $\begin{array}{l}40 \cdot 3 \\
33 \cdot 2\end{array}$ \\
\hline $\begin{array}{l}\text { London } \\
\text { Harrogate } \\
\text { Cardiff }\end{array}$ & $\begin{array}{l}\ddot{.} \\
\cdots\end{array}$ & $\begin{array}{r}24 \cdot 2 \\
2.5 \\
8.9\end{array}$ & $\begin{array}{r}18 \cdot 6 \\
4 \cdot 5 \\
5 \cdot 5\end{array}$ & $\begin{array}{r}21 \cdot 1 \\
5 \cdot 0 \\
7 \cdot 5\end{array}$ & $\begin{array}{r}15 \cdot 4 \\
3 \cdot 6 \\
6 \cdot 8\end{array}$ \\
\hline
\end{tabular}

* At the sites which generally gave the highest measurements in the towns.

respiratory disability; it has provided support for the opinion that sulphur dioxide is probably not the most important component of atmospheric pollution so far as the aetiology of chronic bronchitis is concerned; and it has shown that, despite the heavy deposition of grit in and around an integrated steel works, the amount of respirable particulate pollution to which employees are exposed is surprisingly small and well below danger level.

A generous grant from the Nuffield Foundation, for which we are most grateful, made this investigation possible. It is with pleasure that we acknowledge our indebtedness to Richard Thomas and Baldwins Limited and the Steel Company of Wales Limited for permission to carry out the investigation and to their Managements and the Trades Unions for their support while it was in progress. In addition we are most grateful to Dr. J. G. Jones and Dr. R. B. Body for the help and advice they and their staffs gave us at the two works. Our thanks are due to Dr. Marjorie Clifton of the Warren Spring Laboratory, Ministry of Technology, for the loan of monitoring apparatus for the measurement of urban pollution and for help and advice at all times. Finally, we wish to express our gratitude to Dr. J. Howlett and Mrs. J. Lay of the Atlas Computer Laboratory, Chilton, Berks, for the invaluable help they and their staff gave us with the analysis of our data.

\section{References}

Angel, J. H., Fletcher, C. M., Hill, I. D., and Tinker, C. M. (1965). Respiratory illness in factory and office workers. A study of minor respiratory illnesses in relation to changes in ventilatory capacity, sputum characteristics, and atmospheric pollution. Brit. J. Dis. Chest, 59, 66-80.

Brinkman, G. L., and Coates, E. O. (1962). The prevalence of chronic bronchitis in an industrial population. Amer. Rev. resp. Dis., 86, 47-54.

Buck, S. F., and Brown, D. A. (1964). Mortality from lung cancer and Bronchitis in relation to Smoke and Sulphur Dioxide Concentration, Population Density and Social Index. Tobacco Research Council. Research Paper No. 7. 
Fairbairn, A. S., and Reid, D. D. (1958). Air pollution and other local factors in respiratory disease. Brit. J. prev. soc. Med., 12, 94-103.

Ferris, B. G., Burgess, W. A., and Worcester, J. (1967). Prevalence of chronic respiratory disease in a pulp mill and a paper mill in the United States. Brit. J. industr. Med., 24, 26-37.

Greenwald, 1. (1954). Effects of inhalation of low concentrations of sulfur dioxide upon man and other animals. Arch. industr. Hyg., $10,455-475$.

Higgins, I. T. T., and Cochrane, A. L. (1961). Chronic respiratory disease in a random sample of men and women in the Rhondda Fach in 1958. Brit. J. industr. Med., 18, 93-102.

_- Oldham, P. D., Cochrane, A. L., and Gilson, J. C. (1956). Respiratory symptoms and pulmonary disability in an industrial town. Brit. med. J., 2, 902-910.

Holland, W. W., and Reid, D. D. (1965). The urban factor in chronic bronchit is. Lancet, 1, 445-448.

Hyatt, R. E., Kistin, A. D., and Mahan, T. K. (1964). Respiratory disease in southern West Virginia coal miners. Amer. rev. resp. Dis., 89, 387-401.

Lawther, P. J., Martin, A. E., and Wilkins, E. T. (1962), Epidemiology of Air Pollution. Public Health Papers No. 15, W.H.O., Geneva.

Lowe, C. R. (1969). Industrial bronchit is. Brit. med. J., 1, 463-468.

-, Pelmear, P. L., Campbell, H., Hitchens, R. A. N., Khosla, T., and King, T. C. (1968). Bronchit is in two integrated steel works. I. Ventilatory capacity, age, and physique of non-bronchitic men. Brit. J. prev. soc. Med., 22, 1-11.

Medical Research Council (1960). Standardized questionnaires on respiratory symptoms. Brit. med.J., 2, 1665.
Ministry of Labour (1966). Dust and Fumes in Factory Atmospheres, 3rd ed. [Safety Health and Welfare], New Series No. 8, H.M.S.O., London.

Ministry of Technology, Warren Spring Laboratory (1961). National Survey of Air Pollution: the use of the daily instrument for measuring smoke and sulphur dioxide. H.M.S.O., London.

- (1967). The Investigation of Atmospheric Pollution 1958-1966. H.M.S.O., London.

Paul, R. (1961). Chronic bronchit is in African miners and non-miners in Northern Rhodesia. Brit. J. Dis. Chest., 55, 30-34.

Pemberton, J. (1956). Chronic bronchit is, emphysema, and bronchial spasm in bituminous coal workers. Arch. industr. Hlth, 13, 529-544. -, and Goldberg, C. (1954). Air pollution and bronchitis. Brit. med.J., 2, 567-570.

Registrar General. (1958). Decennial Supplement, England and Wales, 1951. Occupational Mortality. Part II. H.M.S.O., London.

Skalpe, I. O. (1964). Long-term effects of sulphur dioxide exposure in pulp mills. Brit. J. industr. Med., 21, 69-73.

Sluis-Cremer, G. K., Walters, L. G., and Sichel, H. S. (1967). Chronic bronchitis in miners and non-miners: an epidemiological survey of a community in the gold-mining area in the Transvaal. Brit. J. industr. Med., 24, 1-12.

Stocks, P. (1959). Cancer and bronchitis mortality in relation to atmospheric deposit, and smoke. Brit. med. J., 1, 74-79.

Warner, C. G., Davies, G. M., Jones, J. G., and Lowe, C. R. (1969). Bronchit is in two integrated steel works. II. Sulphur dioxide and particulate atmospheric pollution in and around the two works. Ann. occup. Hyg., 12, 151-170.

Received for publication May 21, 1969. 